\title{
Use of redox mediators for the enhanced degradation of selected nitrophenols
}

\author{
Mohammed Yaseen $^{1}$ (D) Basavaraju Manu ${ }^{2} \cdot$ Najaruddin Kudri $^{3} \cdot$ H. S. Govardhanaswamy ${ }^{1}$
}

Received: 17 December 2018 / Accepted: 7 October 2019 / Published online: 24 October 2019

(c) The Author(s) 2019

\begin{abstract}
In the present study, sequential anaerobic-aerobic treatment was used for the enhanced degradation of selected nitrophenols. Five identical reactors were used to assess the degradation of 2-nitrophenol and 2,4-dinitrophenol. Reactor 1 was used as control, and another four reactors were operated in anaerobic phase followed by sequential aerobic treatment. The performance of reactors was studied for nitrophenol concentrations of 5,10,20 and $40 \mathrm{mg} / \mathrm{l}$ and in next phase effect of redox mediators [lawsone and anthraquinone sulphonic acid (AQSA)], along with kinetics of degradation studied for $40 \mathrm{mg} / \mathrm{l}$ of nitrophenols. More than $98 \%$ degradation of nitrophenols was achieved at lower concentrations but for $40 \mathrm{mg} / \mathrm{l} \mathrm{removal}$ percentage was reduced, and also COD inhibition was observed. However, with the addition of redox mediators, both nitrophenols and COD removal percentage were greater than $95 \%$ and $85 \%$, respectively. Kinetics of degradation revealed that the rate of degradation was found to increase with the increase in concentration of redox mediators from 10 to $20 \mathrm{mg} / \mathrm{l}$, and it was found that degradation was faster with the use of AQSA in comparison with lawsone solution. It indicates that use of redox mediators is favourable for the enhanced degradation of nitrophenols. Sequential anaerobic-aerobic treatment is possible potential treatment method for treating nitrophenolic wastewaters.
\end{abstract}

Keywords Redox mediators $\cdot$ Sequential anaerobic-aerobic treatment $\cdot$ Enhanced degradation

\section{Introduction}

One of the characteristics that best define today's society in what are known as developed countries is the production of waste; approximately, $23 \%$ of the world's populations live in developed countries, consume $78 \%$ of the resources and produce $82 \%$ of the waste products. At present, there are

Mohammed Yaseen

sameercv018@gmail.com

Basavaraju Manu

bmanu8@yahoo.co.in

Najaruddin Kudri

chemnazar@gmail.com

H. S. Govardhanaswamy

hsgswamy@gmit.ac.in

1 Department of Civil Engineering, G.M. Institute of Technology, Davanagere, Karnataka, India

2 Department of Civil Engineering, National Institute of Technology Karnataka Surathkal, Mangalore, India

3 Marafiq (Power and Water Utility Company for Jubail and Yanbu), Yanbu, Kingdom of Saudi Arabia some five million known substances registered, of which approximately 70,000 are widely used worldwide, and it is estimated that 1000 new chemical substances are added to the list each year.

Nitrophenols are produced industrially by the reaction of chlorides with sodium hydroxide at temperatures close to $200 \mathrm{C}$. Nitration of benzene to produce nitrobenzene and dinitrobenzene is commercially important technology. They have been used worldwide as an intermediate in the production of explosives, pharmaceuticals, pesticides, pigments, dye, wood preservatives and rubber chemicals (Karim and Gupta 2000). Nitrophenols are among the most widely used industrial organic compounds.

These nitrophenols are environmentally undesirable being noxious in nature and causing intense colouration of process waste water (Du et al. 2006). In particular, these compounds tie up the oxygen that is necessary to support life in the streams to which the waste discharges. They can cause substantial quantities of suspended matter and excessive colouration at the point of discharge. They can cause an objectionable taste and odour in potable water and fish flesh. Nitrophenols are referred to as toxic compounds because of

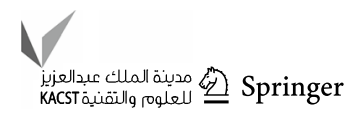


poor biodegradability. Due to their widespread usage and toxicity, these compounds present a serious environmental problem. Nitrophenols may enter the environment from a variety of sources. Significant amount of nitrophenols are also found in the effluents from petrochemical industries.

\section{Exposure to nitrophenols}

Nitrophenols range from slight to strong oxidizing agents. If mixed with reducing agents, including hydrides, sulphides and nitrides, they may begin a vigorous reaction that culminates in a detonation. The aromatic nitro compounds may explode in the presence of a base such as sodium hydroxide or potassium hydroxide even in the presence of water or organic solvents. The explosive tendencies of aromatic nitro compounds are increased by the presence of multiple nitro groups.

Small amounts of the two substances can be found in the air, water and soil. Therefore, breathing air, drinking water and eating foods grown in soils that contain these substances can expose individuals with nitrophenols. Some people may be exposed to higher than background levels of nitrophenols. Workers who produce or process these chemicals may be exposed to higher doses, particularly during spills or accidents. Workers involved in cleaning up hazardous waste or spills that contain these chemicals and pesticide applicators are especially subjected to higher than background levels of exposure. People who use certain pesticides or who drink well water near farming areas where certain pesticides are used may also be exposed to higher than background levels of nitrophenols.

\section{Need for the study}

2-nitrophenol (2-NP), 4-nitrophenol (4-NP) and 2,4-dinitrophenol (2,4-DNP) are listed on the US Environmental Protection Agency's "Priority Pollutant List". Various studies have been carried out to detoxify and degrade these compounds. The US EPA recommends restricting their concentrations in natural waters to below $10 \mathrm{ng} / \mathrm{l}$. Despite the fact that toxic compounds are characterized as being recalcitrant, they can be degraded biologically using adapted microorganisms. A limited number of studies have examined the degradation of nitrophenols using anaerobic processes (Ribas et al. 1997).

The conventional treatment systems like activated sludge process, aerated lagoons and trickling filters do not remove nutrients completely, while the continuous flow systems use large space for construction. These limitations easily overcome in sequential process, which requires less space and is also capable of nutrient and organic carbon removal.

This laboratory scale studies are carried out to explore the potential of removal or nitrophenols and effect of redox mediators on its removal efficiency by sequential anaerobic and aerobic process.

\section{Materials and methods}

The experiments were performed using five bench-scale $S B R$ reactors $(R 1, R 2, R 3, R 4$ and $R 5)$ having a working volume of 31 for anaerobic phase and 1.51 volume for aerobic phase, respectively, to study the nutrient as well as organic substrate removal; microbial inoculum (seed sludge) used was cow dung in slurry form which is used as the seeding material for developing nitrophenol removal organisms.

All chemicals were obtained from Merck chemicals of analytical grade except the anthraquinone 4-sulphonic acid which is imported from Merck, Germany, and for preparation of lawsone solution, lawsone leaves obtained from lawsone plant are dried in the presence of sunlight and powdered, sieved and a stock solution of $1000 \mathrm{mg} / \mathrm{l}$ is prepared and used as natural redox mediator for the present study.

Nitrophenols are a family of nitrated phenols with the formula $\mathrm{HOC}_{6} \mathrm{H}_{4} \mathrm{NO}_{2}$ range from slight to strong oxidizing agents. 2-nitrophenol also known as 2-hydroxynitrobenzene is a yellow crystalline solid having aromatic odour with a specific gravity of 1.49 , having a molecular formula $\mathrm{C}_{6} \mathrm{H}_{5} \mathrm{NO}_{3}$. With a water solubility of $2 \mathrm{~g} / \mathrm{l}$ (Michael et al. 1990).

2,4-dinitrophenol also known as 1-hydroxy-2,4-dinitrobenzene is a pale yellow crystalline solid that has a sweet, musty odour. It sublimes when carefully heated and is volatile with steam. It is soluble in water (sparingly) having a molecular formula $\mathrm{C}_{6} \mathrm{H}_{4} \mathrm{~N}_{2} \mathrm{O}_{5} / \mathrm{C}_{6} \mathrm{H}_{3}(\mathrm{OH})\left(\mathrm{NO}_{2}\right)_{2}$.

\section{Redox mediators}

Lawsonia inermis (Henna) contains a red-orange pigment, the molecule of which is also known as hennotannic acid. Chemically, the molecule of lawsone is 2-hydroxy-1,4-naphthoquinone. Industrial classifications also describe lawsone as natural orange. Pure lawsone is an orange powder, with a melting point higher than $192{ }^{\circ} \mathrm{C}$ (Choi et al. 2002).

Anthraquinone 4-sulphonic acid belongs to sulphonate family having five oxidation states with a chemical formula $\mathrm{C}_{14} \mathrm{H}_{7} \mathrm{Na} \mathrm{O} \mathrm{O}_{5} \mathrm{~S}$ (Keck et al. 1997).

The addition of these two quinoid Redox mediators is tested on the degradation of nitrophenols and their ability of degradation is compared in the present study.

\section{Experimental methodology}

A bench-scale SBR with working volume of 31 for anaerobic phase was seeded with 1.51 of cow dung in the beginning glucose, sodium bicarbonate and other nutrients 
2-3 ml/l listed in the table is feeded with 11 influent water daily and simultaneously aerobic phase of reactors in also seeded with 0.51 of cow dung slurry and feeded with same influent as above till the start-up of reactors which was 45 days for anaerobic phase and 25 days for aerobic phase, respectively. Trace metals solution was prepared in distilled water by dissolving $5 \mathrm{~g} \mathrm{MgSO} 4 \cdot 7 \mathrm{H}_{2} \mathrm{O}$, $6 \mathrm{~g} \mathrm{FeCl}_{2} \cdot 4 \mathrm{H}_{2} \mathrm{O}, 0.88 \mathrm{~g} \mathrm{COCl}_{2} \cdot 4 \mathrm{H}_{2} \mathrm{O}_{2} 0.1 \mathrm{~g} \mathrm{H}_{3} \mathrm{BO}_{3}, 0.1 \mathrm{~g}$ $\mathrm{ZnSO}_{4} \cdot 7 \mathrm{H}_{2} \mathrm{O}_{2} 0.05 \mathrm{~g} \mathrm{CuSO}_{4} \cdot 5 \mathrm{H}_{2} \mathrm{O}, 1 \mathrm{~g} \mathrm{NiSO}_{4} \cdot 8 \mathrm{H}_{2} \mathrm{O}, 5 \mathrm{~g}$ $\mathrm{MnCl}_{2} \cdot 4 \mathrm{H}_{2} \mathrm{O}$ and $0.64 \mathrm{~g}\left(\mathrm{NH}_{4}\right) 6 \mathrm{MO}_{7} \mathrm{O}_{24} \cdot 4 \mathrm{H}_{2} \mathrm{O}$ in 11 distilled water (Karim and Gupta 2001). One millilitre of this solution was added per litre of the synthetic feed solution. After the start-up nitrophenols are loaded in the increasing concentrations from 5 to $40 \mathrm{mg} / \mathrm{l}$ monitoring each concentration for 15 days and in the next step for $40 \mathrm{mg} / \mathrm{l}$ of nitrophenol concentration, effect of redox mediators is studied.

Subsequently after the start-up, the performance of reactor was monitored under four different nitrophenol loadings of 5,10, 20 and $40 \mathrm{mg} / \mathrm{l}$ each concentration is monitored for 15 days with nitrophenol and COD removal, further the study was extended on the effects of redox mediators on nitrophenol removal. Redox mediators used for study are lawsone solution used as natural redox mediator and anthraquinone 4-sulphonic acid for $40 \mathrm{mg} / \mathrm{l}$ of nitrophenol loading with 10 and $20 \mathrm{mg} / \mathrm{l}$ of both redox mediators (Lapenait et al. 2004).

The SBR used during the study was operated totally for 165 days through sequences of fill, react settle and draw (decant). In the fill stage, synthetic wastewater water was added to the reactor; the react phase was divided into anaerobic react where the reaction took place anaerobically and aerobic react where reaction took place by supplying air using aquarium pump connected to diffuser stones. During the settle phase, wastewater was allowed to settle, and in decant step, the supernatant liquid was decanted (Gorontzy et al. 1993).

The HRT was 3 days for anaerobic reactors and SRT was 90 days OLR OF $1 \mathrm{~kg} \mathrm{COD} / \mathrm{M}^{3}$-day is maintained throughout the operation and SVI was in the range of $100-125 \mathrm{ml} / \mathrm{g}$ (Karim and Gupta 2000).

\section{Sequential aerobic treatment of anaerobic effluent}

In the next step, two aerobic reactors are started up using the same seed as cow dung of 0.51 volume along with $1 \mathrm{~g}$ of glucose and $1 \mathrm{~g}$ of sodium bicarbonate solution daily till the start-up which took 25 days. After the start-up, anaerobic effluent is treated using sequential aerobic reactors.

In the present study 1.5 days of HRT, 45 days of $\mathrm{SRT}$, OLR of $1 \mathrm{~kg} \mathrm{COD} / \mathrm{m}^{3}$-day and SVI in the range of $100-125 \mathrm{ml} / \mathrm{g}$ is maintained throughout the operation of the reactors.

\section{Analytical procedures}

The samples were collected for the analysis of various parameters at the end of anaerobic and aerobic phases of the SBR as well as influent and effluent of the batch reactor. During continuous monitoring in a cycle, samples were collected every $24 \mathrm{~h}$ and analysed for the various parameters.

All the samples were filtered before analysis and were analysed for $\mathrm{pH}, \mathrm{COD}$, alkalinity, ORP, MLSS, MLVSS and nitrophenols in accordance with the Standard Methods 21st Edition, APHA (2005).

$\mathrm{pH}$ was measured by glass electrode $\mathrm{pH}$ meter, COD by closed reflux colorimetric method, alkalinity by titrimetric method and ORP by glass electrode-calomel electrode method.

Nitrophenols was analysed by Cintral UV-VIS spectrophotometer, 2-nitrophenol was analysed at wavelength of $280 \mathrm{~nm}$, and 2,4-DNP was analysed for $400 \mathrm{~nm}$.

Mixed liquor suspended solids and mixed liquor volatile suspended solids were analysed by vapourizing $50 \mathrm{ml}$ of raw sample with filtration through Whatman filter paper in hot air oven at $103{ }^{\circ} \mathrm{C}$, and MLVSS were analysed by vapourizing the samples at $550{ }^{\circ} \mathrm{C}$; this is done as done by the previous researchers.

COD removal efficiency was analysed by closed reflux colorimeter at $600 \mathrm{~nm}$ and percentage removal efficiency is calculated.

\section{Nitrophenols analysis by spectroscopy method}

Nitrophenols were analysed colorimetrically, and absorbance was measured at $280 \mathrm{~nm}$ for 2-NP and 2,4-DNP was measured at $400 \mathrm{~nm}$ (Babes and Engewald 2000). $100 \mathrm{mg} / \mathrm{l}$ of both 2-NP and 2,4-DNP stock solution was prepared by dissolving $0.1 \mathrm{~g}$ of 2-NP and 2,4-DNP solution from that different concentrations like $5 \mathrm{mg} / 1,10 \mathrm{mg} / 1,20 \mathrm{mg} / \mathrm{l}$ and $40 \mathrm{~g} / \mathrm{l}$ are prepared by taking required quantity from stock and diluting it with distilled water.

For calibration, standards containing $10 \mathrm{mg}, 15 \mathrm{mg}$, $20 \mathrm{mg}, 25 \mathrm{mg}$ and $40 \mathrm{mg}$ were prepared for both 2-NP and 2,4-DNP by transferring $10 \mathrm{ml}, 15 \mathrm{ml}, 20 \mathrm{ml}, 25 \mathrm{ml}$ and $40 \mathrm{ml}$ into $100-\mathrm{ml}$ standard flasks, and these flasks were made up to $100 \mathrm{ml}$ by adding distilled water; a blank was prepared with distilled water without nitrophenols.

The absorbances of these standard solutions were measured at $280 \mathrm{~nm}$ for 2-NP and $400 \mathrm{~nm}$ for 2,4-DNP using UV spectrophotometer against the distilled water blank; for analysis of nitrophenols, the unknown samples was measured at $280 \mathrm{~nm}$ for $2-\mathrm{NP}$ and $400 \mathrm{~nm}$ for 2,4-DNP using UV spectrophotometer against control reactor blank. 


\section{Results and discussion}

Sequential anaerobic and aerobic treatment are the most efficient methods of wastewater containing nitrophenolic waste because of its advantage like high-quality effluent at varying loads, reduction in space, few mechanical parts and power savings due to lower oxygen requirements, while its limitation is its batch operation mode, requiring on and off of influent feed, aeration and effluent decanting controls.

\section{Start-up of anaerobic and aerobic reactors}

Initially, the reactors are seeded with cow dung of 11 volume total to all the three reactors, and daily it is feeded with feed as follows: $2-3 \mathrm{mg} / \mathrm{l}$ of trace metal solution prepared in distilled water by dissolving per litre comprising of following $\mathrm{MgSO}_{4} 5 \mathrm{~g} / \mathrm{l}, \mathrm{FeCl}_{2} \cdot 4 \mathrm{H}_{2} \mathrm{O}-6 \mathrm{~g} / \mathrm{l}, \mathrm{CO} \cdot \mathrm{Cl}_{2} 0.88 \mathrm{~g} / \mathrm{l}$, $\mathrm{H}_{3} \mathrm{BO}_{3}-0.1 \mathrm{~g} / \mathrm{l}, \mathrm{ZnSO}_{4} 0.7 \mathrm{H}_{2} \mathrm{O}-0.1 \mathrm{~g} / 1, \mathrm{CuSO}_{4} 0.05 \mathrm{~g} / \mathrm{l}$, $\mathrm{NisO}_{4}-1 \mathrm{~g} / \mathrm{l}, \mathrm{MnCl}_{2}-5 \mathrm{~g} / \mathrm{l},\left(\mathrm{NH}_{4}\right)_{6} \cdot \mathrm{MO}_{7} \mathrm{O}_{24} \cdot 4 \mathrm{H}_{2} \mathrm{O}-0.64 \mathrm{~g} / \mathrm{l}$, $\mathrm{CaCL}_{2} \cdot 0.2 \mathrm{H}_{2} 0-5 \mathrm{~g} / 1$ with $1 \mathrm{~g}$ of glucose and $1 \mathrm{~g}$ of sodium bicarbonate solution to the reactors for 1 month in the acclimatization stage. COD removal was found as $65 \mathrm{mg} / \mathrm{l}$ for five consecutive days. Effluent $\mathrm{pH}$ was in the range of 6.5-7, effluent alkalinity was in the range of 500-1200 mg/l, MLVSS was $12.5 \mathrm{~g} / \mathrm{l}$, whereas MLSS was $15.5 \mathrm{~g} / \mathrm{l}$ (Donlon et al. 1996) (Fig. 1).

\section{Sequential aerobic reactors}

In the next step, two aerobic reactors are started up using the same seed as cow dung of 0.51 volume along with $1 \mathrm{~g}$ of glucose and $1 \mathrm{~g}$ of sodium bicarbonate solution daily till the start-up which took 25 days. COD removal was $80 \%$ for 5 consecutive days. $\mathrm{pH}$ was in the range of $6.5-7$, MLVSS was 12.24 and MLSS was $15.5 \mathrm{~g} / \mathrm{l}$ (Fig. 2).

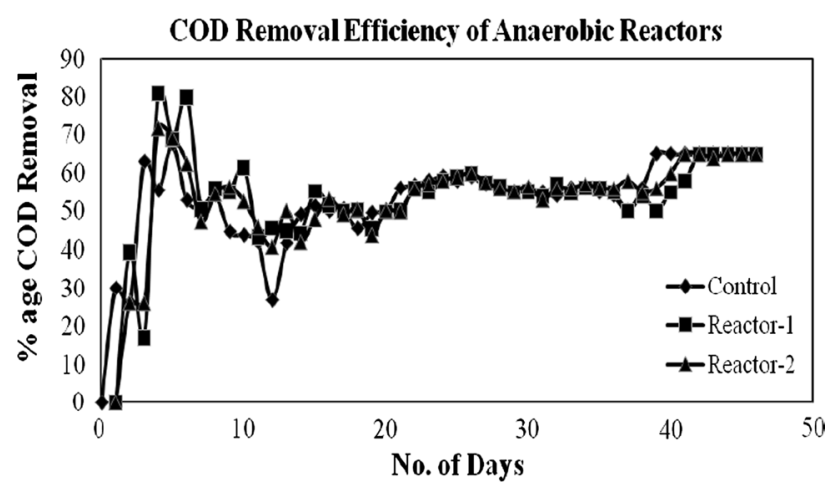

Fig. 1 COD removal efficiencies of anaerobic set of three reactors during the start-up phase

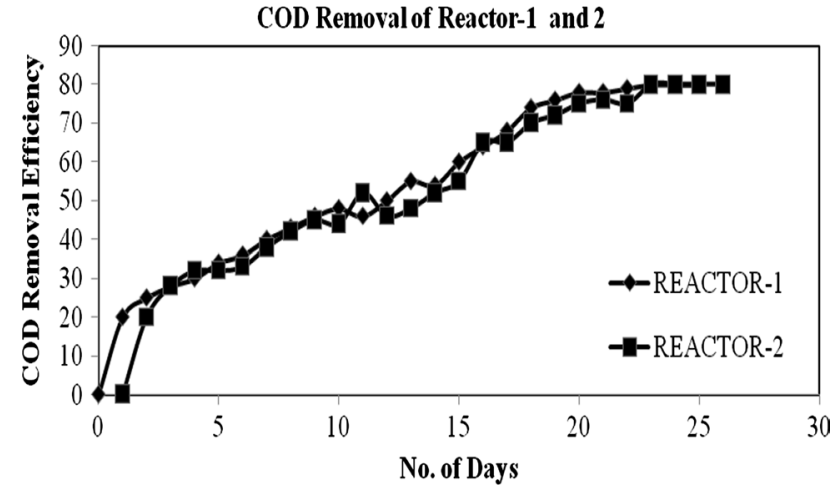

Fig. 2 COD removal efficiencies of aerobic set of reactors during the start-up phase

\section{Effect of nitrophenol loading and anaerobic degradation}

After start-up of both the reactors, nitrophenols loading is started from 46th day to the reactors from 5 to $40 \mathrm{mg} / \mathrm{l}$, and influent alkalinity was in the range of $1000-3000 \mathrm{mg} / \mathrm{l}$ and effluent alkalinity was in the range of 500-2300 $\mathrm{mg} / \mathrm{l}$ for the whole cycle of operation. Each concentration was monitored for 15 days.

From Fig. 3, it can be seen that in anaerobic reactors COD removal with reference to control reactor for $5 \mathrm{mg} / \mathrm{l}$ of $2-\mathrm{NP}$ as well for $2,4-\mathrm{DNP}$ was $65 \%$; for $10 \mathrm{mg} / \mathrm{l}$, it was $65 \%$; for $20 \mathrm{mg} / \mathrm{l}$ of $2-\mathrm{NP}$, it was $65 \%$; for $2,4-\mathrm{DNP}$, it was $60 \%$; and for $40 \mathrm{mg} / \mathrm{l}$ of $2-\mathrm{NP}$, it was $55 \%$ and for $2,4-\mathrm{DNP}$, it was $50 \%$. And it can be concluded that as nitrophenol concentration increases, COD inhibition was observed due to the toxic effect on biomass (Karim and Gupta 2002).

From Figs. 3 and 4, it can be seen that the NP removal for $5 \mathrm{mg} / \mathrm{l}$ of $2-\mathrm{NP}$ was $80 \%$; for 2,4-DNP, it was $75 \%$; for $10 \mathrm{mg} / \mathrm{l}$ of $2-\mathrm{NP}$, it was $80 \%$; for $2,4-\mathrm{DNP}$, it was $78 \%$; for $20 \mathrm{mg} / \mathrm{l}$ of $2-\mathrm{NP}$, it was $70 \%$; for $2,4-\mathrm{DNP}$, it was $65 \%$; for $40 \mathrm{mg} / \mathrm{l}$ of $2-\mathrm{NP}$, it was $64 \%$; and for 2,4-DNP, it was $62 \%$. As the concentration of pollutant increases, the removal

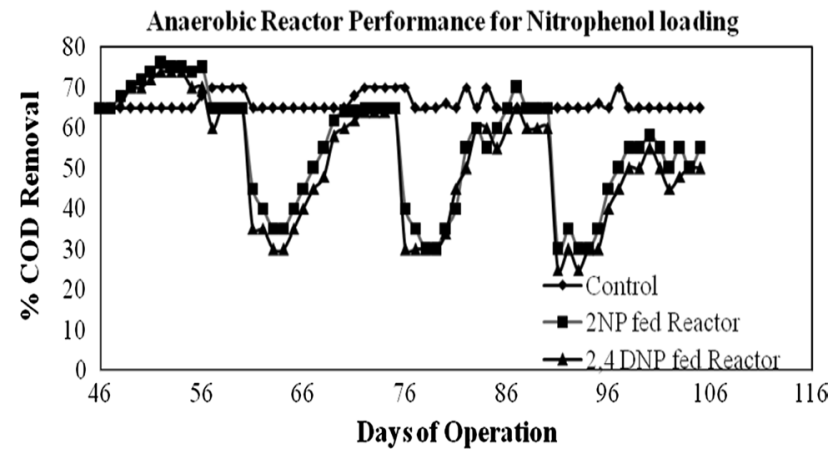

Fig. 3 COD removal of anaerobic reactors during nitrophenol loading 


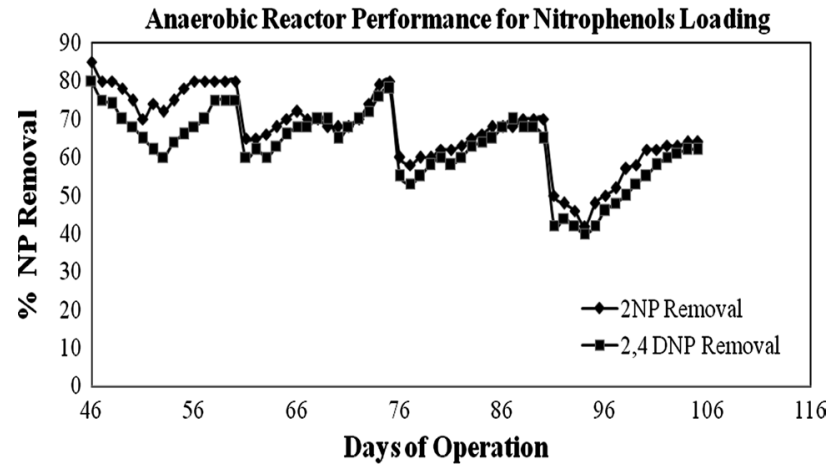

Fig. 4 Nitrophenol removal efficiency for anaerobic reactors

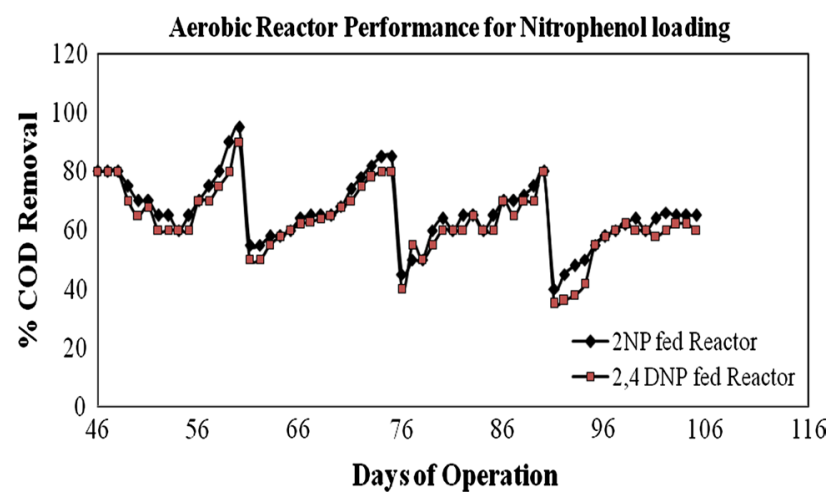

Fig. 5 COD removal for aerobic reactors during nitrophenol loading

efficiency decreased gradually due to the toxic effect on the biomass (Karim and Gupta 2001).

\section{Sequential aerobic degradation}

From Fig. 5, for the sequential aerobic reactor, it can be seen that COD removal for $5 \mathrm{mg} / \mathrm{l}$ of $2-\mathrm{NP}$, it was $95 \%$, for $2,4-$ DNP, it was $90 \%$; for $10 \mathrm{mg} / \mathrm{l}$ of 2-NP, it was $85 \%$, for $2,4-$ DNP, it was $80 \%$; for $20 \mathrm{mg} / \mathrm{l}$ of $2-\mathrm{NP}$, it was $80 \%$, for $2,4-$ DNP, it was $80 \%$; and for $40 \mathrm{mg} / \mathrm{l}$ of $2-\mathrm{NP}$, it was $65 \%$ and for 2,4-DNP, it was $60 \%$. And it can be seen that as the concentration of pollutant increases the removal efficiency decreased gradually due to the toxic effect on the biomass (Fig. 6).

\section{Effect of redox mediators and anaerobic degradation}

From 106th days of operation, the effect of redox mediators lawsone and AQSA was studied with 10 and $20 \mathrm{mg} / \mathrm{l}$ for the nitrophenol concentration of $40 \mathrm{mg} / \mathrm{l}$. Influent alkalinity was in the range of 2000-3000 mg/l. Each concentration of redox mediator was monitored for 15 days, and the results are shown below.

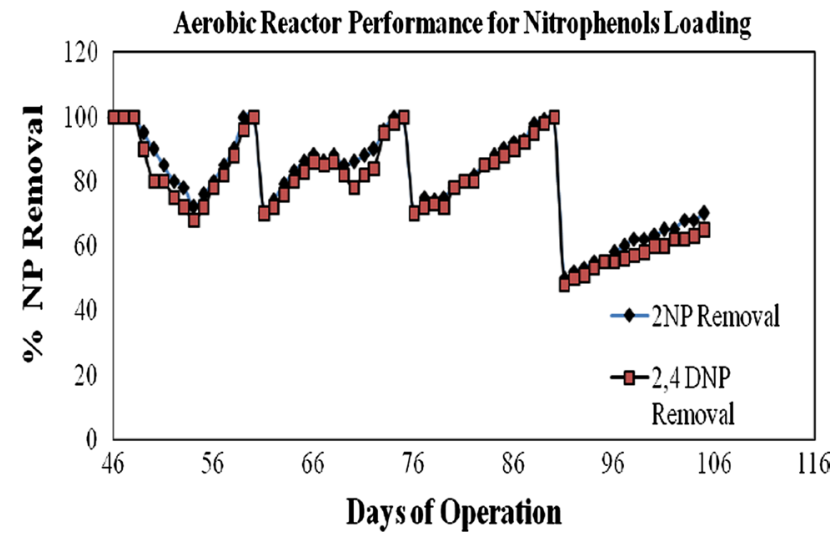

Fig. 6 Nitrophenol removal efficiency for aerobic reactors

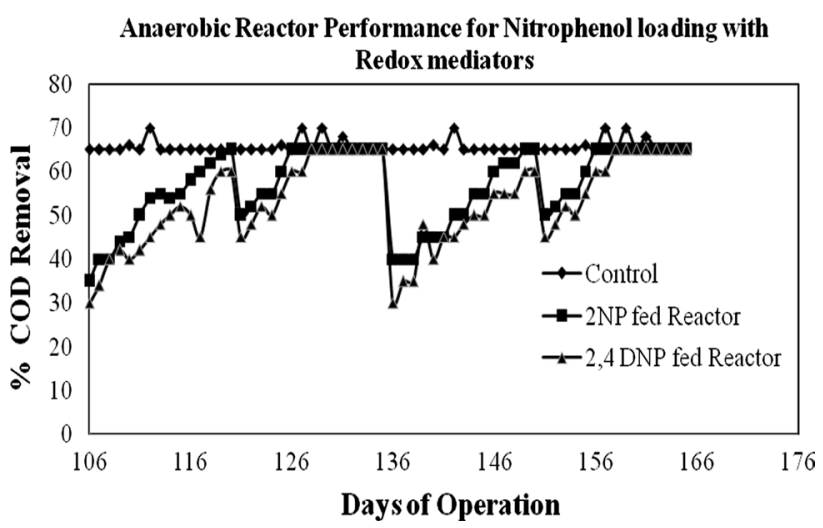

Fig. 7 COD removal for anaerobic reactors for $40 \mathrm{mg} / \mathrm{l}$ with redox mediators

From Fig. 7, for anaerobic reactors, it can be seen that the COD removal for $40 \mathrm{mg} / \mathrm{l}$ with $10 \mathrm{mg} / \mathrm{l}$ lawsone solution for $2-\mathrm{NP}$ is $65 \%$, for $2,4-\mathrm{DNP}$ it is $60 \%$; for $20 \mathrm{mg} / \mathrm{l}$ of lawsone solution for 2-NP, it was 75, for 2,4-DNP it was 70\%; for $10 \mathrm{mg} / \mathrm{l} \mathrm{AQSA}$ of $2-\mathrm{NP}$, it was $65 \%$, for $2,4-\mathrm{DNP}$, it was $60 \%$; for $20 \mathrm{mg} / \mathrm{l} \mathrm{AQSA}$ of $2-\mathrm{NP}$, it was $65 \%$ also for $2,4-$ DNP, it was $65 \%$ which is slightly improved in comparison without the addition of redox mediators.

From Fig. 8 for anaerobic reactors, it can be seen that the NP removal for $40 \mathrm{mg} / \mathrm{l}$ with $10 \mathrm{mg} / \mathrm{l}$ lawsone solution for 2-NP, it was 70\%, for 2,4-DNP, it was $68 \%$; with $20 \mathrm{mg} / \mathrm{l}$ for 2-NP, it was 75\%, for 2,4-DNP, it was 70\%; with $10 \mathrm{mg} / \mathrm{l}$ AQSA for 2-NP, it was 75\%, for 2,4-DNP, it was 73\%; with $20 \mathrm{mg} / \mathrm{l} \mathrm{AQSA}$ for 2-NP, it was 85\%, for 2,4-DNP, it was $80 \%$. Removal efficiency was increased from 65 to $85 \%$ for 2 -NP and $80 \%$ for 2,4-DNP with the addition of redox mediators.

\section{Sequential aerobic degradation}

From Fig. 9 for the sequential aerobic reactors, COD removal efficiency for $40 \mathrm{mg} / \mathrm{l}$, with $10 \mathrm{mg} / \mathrm{l}$ lawsone, was $70 \%$ for

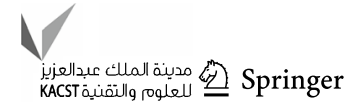




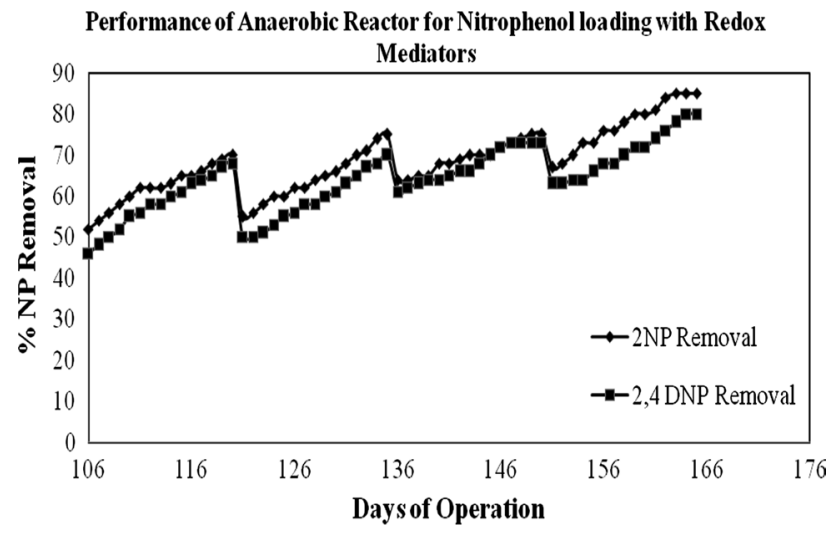

Fig. 8 Nitrophenol removal of anaerobic reactors with redox mediators

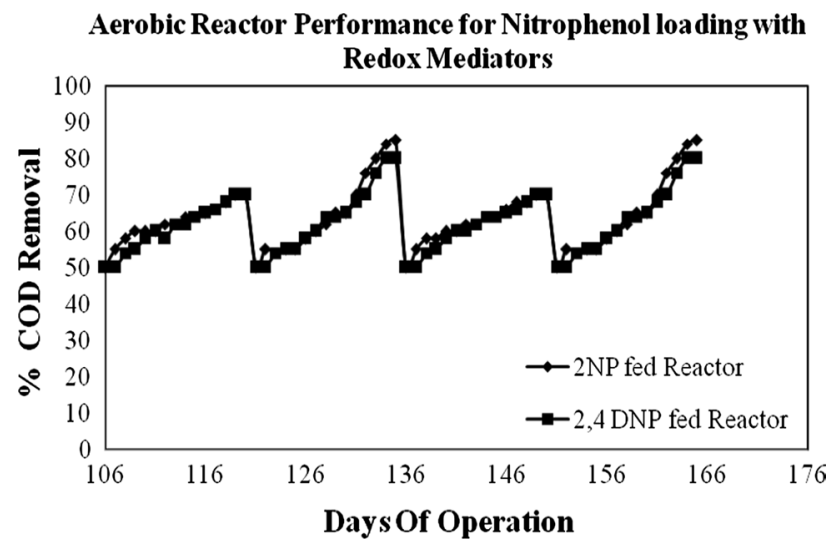

Fig. 9 COD removal for aerobic reactors for $40 \mathrm{mg} / \mathrm{l}$ with redox mediators

both 2-NP and 2,4-DNP; with $20 \mathrm{mg} / \mathrm{l}$ lawsone for 2-NP, it was $85 \%$, for $2,4-\mathrm{DNP}$, it was $80 \%$; with $10 \mathrm{mg} / \mathrm{l} \mathrm{AQSA}$ for both 2-NP and 2,4-DNP, it was 70\%; and with $20 \mathrm{mg} / \mathrm{l} \mathrm{AQSA}$ for $2-\mathrm{NP}$, it was $85 \%$ and for $2,4-\mathrm{DNP}$, it was $80 \%$.

From Fig. 10, for sequential aerobic reactors, it can be seen that the NP removal for $40 \mathrm{mg} / \mathrm{l}$ with $10 \mathrm{mg} / \mathrm{l}$ lawsone solution for 2-NP was $75 \%$, for $2,4-\mathrm{DNP}$, it was $73 \%$; with $20 \mathrm{mg} / \mathrm{l}$ lawsone for $2-\mathrm{NP}$, it was $80 \%$, for $2,4-\mathrm{DNP}$, it was $75 \%$; with $10 \mathrm{mg} / \mathrm{l} \mathrm{AQSA}$ for 2-NP, it was $80 \%$, for $2,4-$ DNP, it was 75\%; and with $20 \mathrm{mg} / \mathrm{l}$ AQSA for 2-NP, it was $100 \%$ for both 2-NP and 2,4-DNP. As the concentration of redox mediators increased, the removal efficiency was seen improved both for 2-NP and 2,4-DNP. Probable reasons for the improved efficiency are increased redox potential and increased cell metabolism of the biomass and increase in the oxidizing capacity due to release of electrons as they are synthetic electron carriers which oxidizes the organic substrate and provides the redox potential needed for the cell activity (Michael et al. 1990).
Performance of Aerobic Reactor for Nitrophenol loading with Redox Mediators

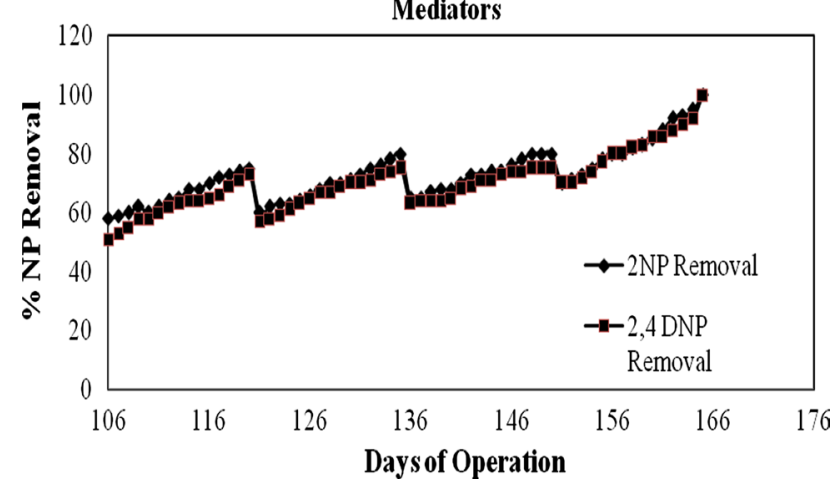

Fig. 10 Nitrophenol removal of aerobic reactors with redox mediators

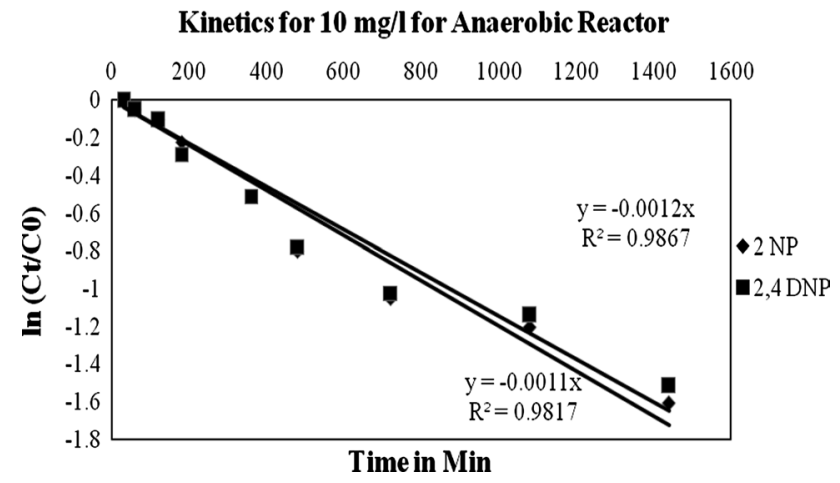

Fig. 11 Kinetics for $10 \mathrm{mg} / \mathrm{l}$ nitrophenol loading

\section{Kinetics of nitrophenol loading}

The removal rate depends on the concentration of the pollutant and the concentration of the redox mediators. The rate of degradation was analysed with different initial concentrations of nitrophenols $(5,10,20$ and $40 \mathrm{mg} / \mathrm{l})$, and $10,20 \mathrm{mg} / \mathrm{l}$ of redox mediators addition were selected for the kinetic study. The experimental data were fitted with first-order kinetics.

Results reveal that data fitted well with first-order kinetic with $R^{2}$ values higher than 0.98 for nitrophenol degradation process (Figs. 11, 12, 13, 14, 15, 16, 17). And it can be seen that the rate of removal values varied between $0.0007-0.0012$ from 10 to $40 \mathrm{mg} / \mathrm{l}$ without redox mediators, whereas with the addition of redox mediators, it varies between $0.0009-0.0018$, and it can be concluded that the rate of removal is high with the addition of redox mediators due to the faster metabolism with the release of electrons which increases the enzymatic activity of the biomass (Petri and Majander 2007).

\section{Kinetics of degradation without redox mediators}

See Figs. 11, 12 and 13. 


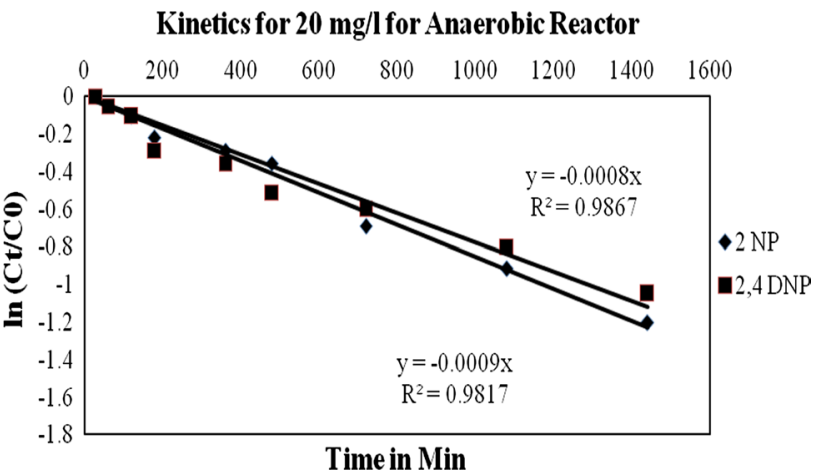

Fig. 12 Kinetics for $20 \mathrm{mg} / \mathrm{l}$ nitrophenol loading

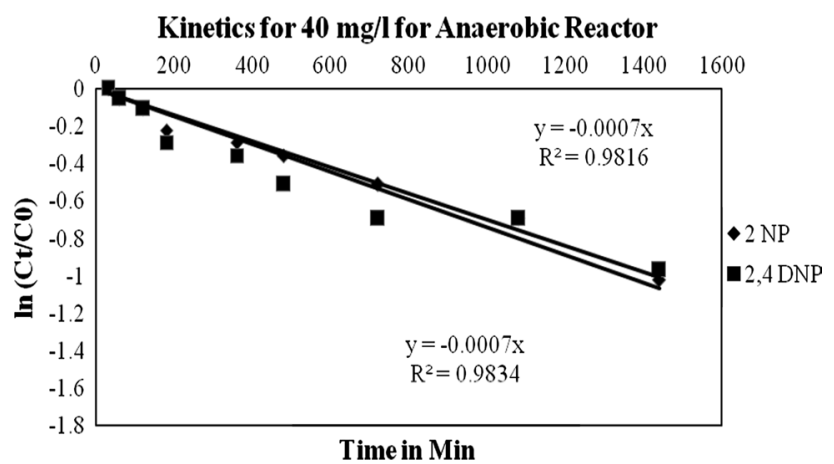

Fig. 13 Kinetics for $40 \mathrm{mg} / \mathrm{l}$ nitrophenol loading

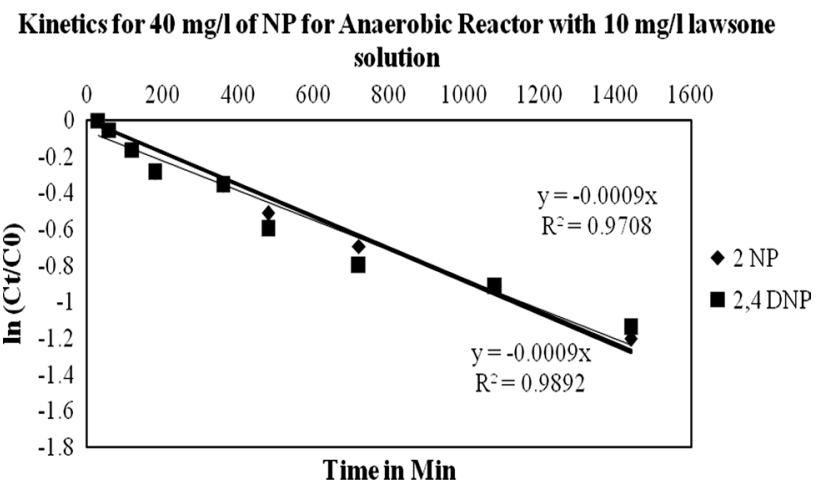

Fig. 14 Kinetics for $40 \mathrm{mg} / \mathrm{l}$ nitrophenol loading with $10 \mathrm{mg} / \mathrm{l}$ lawsone solution

\section{Kinetics of degradation with redox mediators}

The following graphs represent the kinetics of degradation using redox mediators for different concentration of redox mediators.

From the figures above, it can be seen that the rate of removal for $40 \mathrm{mg} / \mathrm{l}$ of $\mathrm{NP}$, with $20 \mathrm{mg} / \mathrm{l}$ of AQSA for 2-NP was 0.0016 and for 2,4-DNP it was 0.0018. And it can be
Kinetics for $40 \mathrm{mg} / \mathrm{l}$ of NP for Anaerobic Reactor with $20 \mathrm{mg} / \mathrm{l}$ lawsone solution

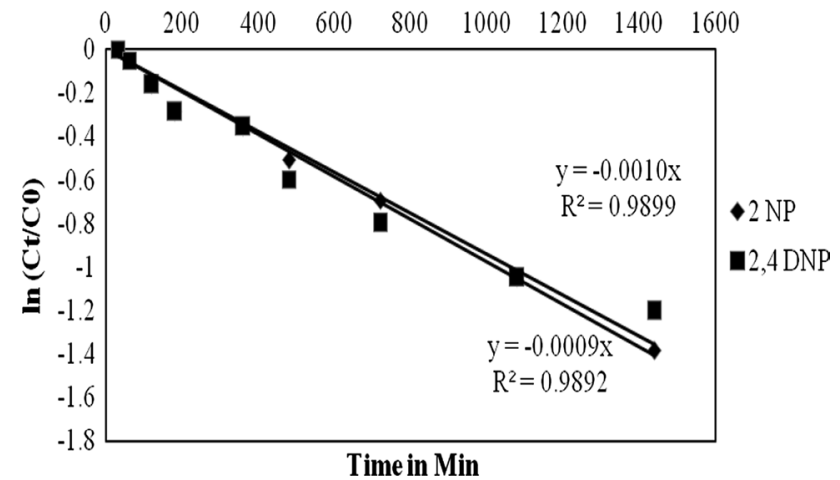

Fig. 15 Kinetics for $40 \mathrm{mg} / \mathrm{l}$ nitrophenol loading with $20 \mathrm{mg} / \mathrm{l} \mathrm{law-}$ sone solution

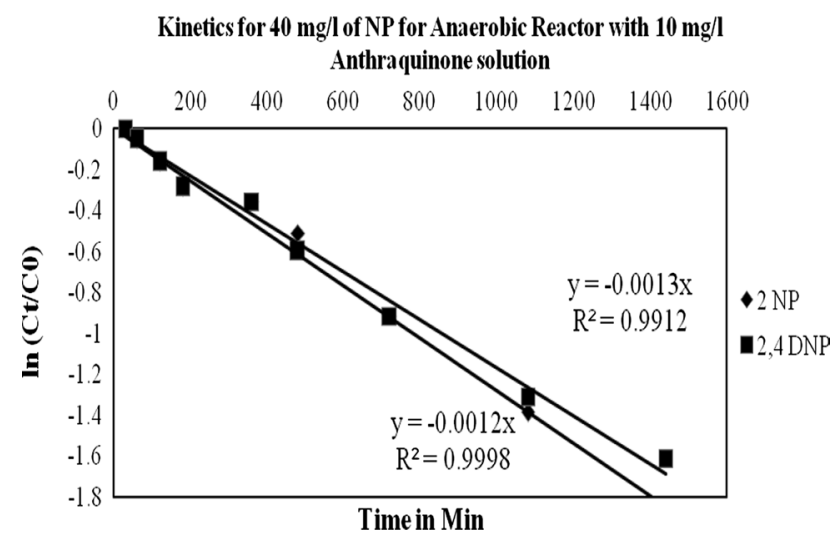

Fig. 16 Kinetics for $40 \mathrm{mg} / 1$ nitrophenol loading with $10 \mathrm{mg} / \mathrm{l}$ AQSA solution

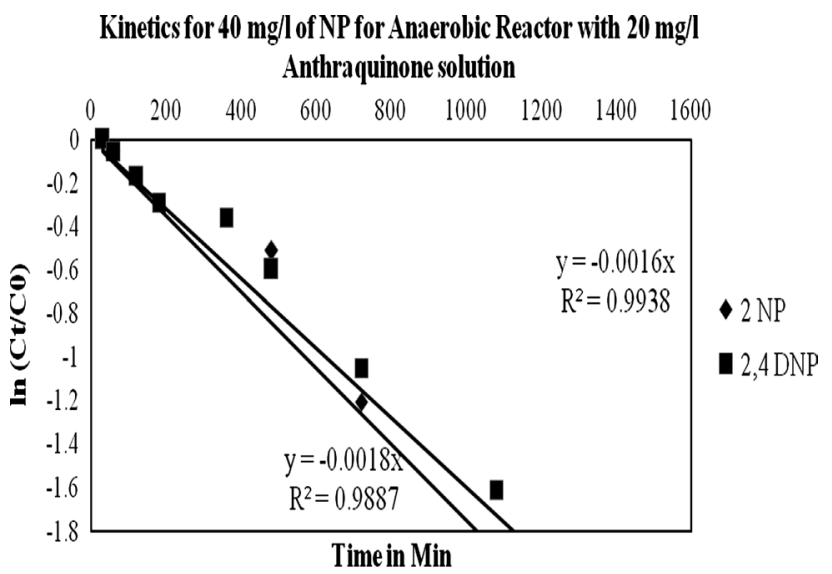

Fig. 17 Kinetics for $40 \mathrm{mg} / \mathrm{l}$ nitrophenol loading with $20 \mathrm{mg} / \mathrm{l}$ AQSA solution

seen that the removal rate is increased sufficiently with the increase in AQSA concentration from 10 to $20 \mathrm{mg} / \mathrm{l}$, and this dosage can be decided as optimum dosage for treating 
$40 \mathrm{mg} / \mathrm{l}$ of nitrophenols. And it can also be seen that at 10 th hour, the removal was $80 \%$ in anaerobic phase which followed by sequential aerobic successfully degraded nitrophenols to more than $95 \%$.

\section{Conclusions}

Nitrophenol removal for $40 \mathrm{mg} / \mathrm{l}$ concentration under sequential anaerobic, aerobic treatment for $2-\mathrm{NP}$ was $70 \%$, for 2,4-DNP, it was $65 \%$. Nitrophenol removal for $40 \mathrm{mg} / \mathrm{l}$ concentration under sequential anaerobic, aerobic treatment with redox mediators for $2-\mathrm{NP}$ was $100 \%$, for 2,4 DNP also, it was $100 \%$. Both lawsone solution and AQSA can be used as redox mediators for the biodegradation of nitrophenols. Degradation was faster with the use of AQSA in comparison with lawsone. COD removal for $40 \mathrm{mg} / \mathrm{l}$ nitrophenols concentration under sequential anaerobic, aerobic treatment for $2-\mathrm{NP}$ was $65 \%$, for $2,4-\mathrm{DNP}$, it was $65 \%$. COD removal for $40 \mathrm{mg} / \mathrm{l}$ nitrophenols concentration under sequential anaerobic, aerobic treatment with redox mediators for 2-NP was $85 \%$, for 2,4 DNP, it was $80 \%$. From the kinetics data, it can be concluded that $20 \mathrm{mg} / 1$ of AQSA is needed to degrade $40 \mathrm{mg} / \mathrm{l}$ of nitrophenols completely by sequential anaerobic and aerobic treatment. Kinetics of degradation shows that degradation was faster with the addition of redox mediators, and at around $10 \mathrm{~h}$ in anaerobic process, $80 \%$ removal was achieved which followed by sequential aerobic treatment removal was more than $98 \%$.

\section{Scope for future work}

Effect of other redox mediators on the removal of nitrophenols can be studied. Experimental investigations can be made on shock loading of nitrophenols with redox mediators. Experimental investigations can be made for mixture of nitrophenols.

\section{Compliance with ethical standards}

Conflict of interest The authors whose names listed in the manuscript certify that they have no affiliations with or involvement in any organization or entity with any financial interests such as (honoraria, educational grants, membership, employment or other equity interest in the subject matter or materials discussed in the manuscript.

Open Access This article is distributed under the terms of the Creative Commons Attribution 4.0 International License (http://creativeco mmons.org/licenses/by/4.0/), which permits unrestricted use, distribution, and reproduction in any medium, provided you give appropriate credit to the original author(s) and the source, provide a link to the Creative Commons license, and indicate if changes were made.

\section{References}

American Public Health Association (APHA), American Water Works Association, and Water Pollution Control Federation (2005) Standard methods for examination of water and wastewater, 21st edn. American Public Health Association, Washington, DC

Babes K, Engewald W (2000) Solid-phase microextraction investigation on nitrophenols for the fast gas chromatography analysis, water, waste, and environment research. Biological fluidized bed reactor. Water Sci Technol 29(12):157

Choi J, Kim N, Kim S, Jung S (2002) Dynamic behaviors of redox mediators within the hydrophobic layers as an important factor for effective microbial fuel cell operation. Bull Korean Chem Soc 24(4):437

Donlon BA, Razo-Flares E, Lettinga G, Field JA (1996) Continuous detoxification, transformation, and degradation of nitrophenols in upflow anaerobic sludge blanket (UASB) reactors. Biotechnol Bioeng 51:439-449

Du Y, Zhou M, Lei L (2006) Role of the intermediates in the degradation of phenolic compounds by Fenton-like process. J Hazard Mater B136:859-865

Gorontzy T, Kuver J, Boterogel KH (1993) Microbial transformations of nitroaromatic compounds under anaerobic conditions. J Gen Microbiol 139:131

Karim K, Gupta SK (2000) Anaerobic treatment of wastewater containing nitrophenolic compounds. Centre for Environmental Science \& Engineering, Indian Institute of Technology, Powai

Karim K, Gupta SK (2001) Biotransformation of nitrophenols in upflow anaerobic sludge blanket reactors. Bioresour Technol 80:179-186

Karim K, Gupta SK (2002) Effects of alternative carbon sources on biological transformation of nitrophenols. Centre for Environmental Science \& Engineering, Indian Institute of Technology, Powai

Keck A, Klein J, Kudlich M, Stolz A, Knackmuss HJ, Mattes R (1997) Reduction of azo dyes by redox mediators originating in the naphthalenesulfonic acid degradation pathway of Sphingomonas sp. strain BN6. Appl Environ Microbiol 63:3684-3690

Lapenait I, Kurtinaitien B, Anusevièius P (2004) Some quinone derivatives as redox mediators for PQQ-dependent glucose dehydrogenase. Biologia 1:20-22

Michael AH, Valerie C, Thomas JR, William JA (1990) Biodegradation of P-nitrophenol in an aqueous waste stream by immobilized bacteria. Appl Environ Microbiol 56(10):2967

Petri P, Majander I (2007) Enhanced organocatalyzed redox processes for sustainable chemical synthesis. Research report for 2007, Department of Chemistry, University of Helsinki (HY)

Ribas F, Frias J, Huguet M, Lucena F (1997) Efficiency of various water treatment processes in the removal of biodegradable and refractory organic matter. Water Res 31(3):639-649

Publisher's Note Springer Nature remains neutral with regard to jurisdictional claims in published maps and institutional affiliations. 